\title{
Response to: Dittrich et al.: Non-Embryo-Destructive Extraction of Pluripotent Embryonic Stem Cells - Overlooked Legal Prohibitions, Professional Legal Consequences and Inconsistencies in Patent Law
}

Replik zu: Dittrich et al.: Embryonenerhaltende Gewinnung pluripotenter Stammzellen - übersehene strafrechtliche Verbote, berufsrechtliche Konsequenzen und patentrechtliche Inkonsequenzen

Authors

Affiliations

\section{T. Faltus ${ }^{1}$, U. Storz ${ }^{2}$}

${ }^{1}$ Juristische und Wirtschaftswissenschaftliche Fakultät, Martin-Luther-Universität Halle-Wittenberg, Halle, Germany

2 Michalski · Hüttermann \& Partner Patentanwälte, Düsseldorf, Germany

\section{Key words}

- non-embryo-destructive

- pre-implantation genetic diagnosis (PIGD)

- stem cell patent

\section{Schlüsselwörter}

- Stammzellgewinnung

- embryonenerhaltend

- Präimplantationsdiagnostik (PID)

- Stammzellenpatent

Deutsche Version unter: http://dx.doi.org/ $10.1055 / \mathrm{s}-0042-110400$
- stem cell extraction

\section{Abstract \\ $\nabla$}

The publication of "Non-embryo-destructive Extraction of Pluripotent Embryonic Stem Cells: Implications for Regenerative Medicine and Reproductive Medicine" by Dittrich et al. in Geburtshilfe und Frauenheilkunde 2015; 75: 1239-1242 [1] describes various possibilities which could result from the non-embryo-destructive extraction of embryonic stem cells from human blastocysts. But implementing this method is more problematic, both legally and ethically, than the authors have represented it to be and is illegal in Germany. German patent DE 102004062184 on the non-embryo-destructive extraction of embryonic stem cells referred to by Dittrich et al. contravenes the higher-ranking case-law of the European Court of Justice. Ultimately, the non-embryo-destructive harvesting of embryonic stem cells with the aim of storing these cells for use in potential therapies as proposed by Dittrich et al. is prohibited in Germany and could lead to criminal prosecution.

\section{Introduction}

13.4.201 accepted 13.6.2016

Bibliography

Dol http://dx.doi.org/

10.1055/s-0042-110400

Geburtsh Frauenheilk 2016; 76 :

1302-1307 @ Georg Thieme

Verlag KG Stuttgart · New York.

ISSN 0016-5751

Correspondence

Dr. Timo Faltus,

Dipl.-Jur., Dipl.-Biol.

Juristische und Wirtschaftswissenschaftliche Fakultät Martin-Luther-Universität

Halle-Wittenberg

Universitätsplatz 3-5

06108 Halle

Germany

timo.faltus@jura.uni-halle.de
Research has begun to focus on the use of human embryonic stem cells to develop new regenerative medicine therapies. However, as shown here using Germany as an example, various parties have adjudged that even early embryos, which includes those required for stem cell extraction, enjoy the right to the protection of their human dignity and physical integrity as guaranteed under the German Constitution. Ever since the first extraction and cultivation of human embryonic stem cells [2], medical, scientific, ethical and legal discussions have been debating the ramifications of extracting and using human embryonic stem cells. The crux of these discussions was and remains the ethical and associated legal status of

\section{Zusammenfassung}

$\nabla$

Die Veröffentlichung von Dittrich et al. „Embryonenerhaltende Gewinnung pluripotenter Stammzellen: Implikationen für die regenerative Medizin und die Reproduktionsmedizin“ Geburtshilfe und Frauenheilkunde 2015; 75: 1239-1242 [1] stellt die Möglichkeiten dar, die sich durch die embryoerhaltende Gewinnung embryonaler Stammzellen aus menschlichen Blastozysten ergeben können. Die Durchführung der Methode ist jedoch rechtlich und ethisch problematischer als von den Autoren dargestellt und in Deutschland rechtlich verboten. Das von Dittrich et al. erwähnte deutsche Patent DE 102004062184 zur embryoerhaltenden Gewinnung von Stammzellen steht im Widerspruch zur höherrangigen Rechtsprechung des Europäischen Gerichtshofs. Schließlich ist die von Dittrich et al. vorgeschlagene embryoerhaltende Gewinnung von Stammzellen zu Zwecken der Asservierung dieser Zellen für eventuelle Therapieverwendungen in Deutschland strafbeschwert verboten.

human embryos at the blastocyst stage. Essentially there are two opposing views on the matter. On the one hand, it has been postulated that fertilization of an oocyte, at the latest when the maternal and paternal gametes fuse, creates an entity with its own moral and legal value, and that this value corresponds to that of a person (who has already been born), meaning that all stages of development from the point of fusion onwards enjoy the same legal protection as those persons do who have already been born, against any heteronomous destruction or exploitation for the benefit of others, as this does not serve the interests of the embryo (for more on this and more references $\mathrm{cf}$. $[3,4])$. The other and opposing view is that the moment in time when this individual moral and legal value is created occurs at a later 
stage of embryonic development. A number of different time points for this have been proposed, including the time when the first neuronal (precursor) cells develop (for more on this and more references $\mathrm{cf}$. $[5,6])$. The consequence of opinions which do not assume that a legal person is created with the fusion of the pronuclei could be that human embryos, for example in the blastocyst stage, can be used and destroyed for the benefit of third parties as long as this use occurs at a time when the embryo has not yet acquired its own legal personality. But the established and generally accepted view in Germany and in the majority of continental European countries is that, with the fusion of the pronuclei of the egg cell and the sperm cell during fertilization of the oocyte at the latest, an embryo is created with its own legal personality and own (constitutional) rights. That is the only way to understand the origin of the German Embryo Protection Act (Embryonenschutzgesetz, ESchG), the legal requirements of the EU patent law and those of the European Patent Convention (EPC). Consequently the embryo-destructive extraction of pluripotent stem cells from embryos is prohibited in Germany (Art. 2 Sect. $1 \mathrm{ESchG}$ ) and the patenting of inventions is barred if, according to the doctrine of the European Court of Justice (ECJ) and the doctrine of the EPC, the invention is based on stem cells which were obtained by destroying an embryo, irrespective of how long ago that occurred (EU Patent Law [7], EPC [8]).

Because of these restrictions, the so-called non-embryo-destructive extraction of stem cells was initially viewed as a way out of this dilemma, which developed out of a divergence between the medical benefit of using embryonic stem cells for new therapies and the embryo's own legal personality, as non-embryo-destructive extraction of stem cells means that the embryo must survive the procedure (extraction of its stem cells). The method would then be comparable on a macroscopic level with allogeneic cell and tissue donations. But given the current legal situation and the generally prevailing opinions on the moral and legal status of human embryos in vitro, this view is short of the mark. In their article, Dittrich et al. [1] do not address this issue, giving the impression that - particularly if the appropriate described and patented method is used - non-embryo-destructive extraction of embryonic stem is legal.

Before the legal situation with regard to the interpretation of the German Embryo Protection Act and the patent jurisdiction of the ECJ and the EPC on the method used for embryo-preserving stem cell extraction are discussed below, it is necessary to understand what the rejection of this form of stem cell extraction from blastocysts may be based on in order to understand the debate about the non-embryo-destructive use of human embryos. Some people are opposed to any form of utilizing human embryos other than those used to assist women to become pregnant because, from the moment of fusion of the egg cell with the sperm cell, even early embryos are considered legal persons who cannot be utilized for the benefit of third parties. But, as will be shown here, rejection of non-embryo-destructive stem cell harvesting can also be based on the fact that - under the current understanding of the constitution and of sub-constitutional laws and the jurisprudence to date - this constitutes the only coherent and consistent interpretation and application of the law, without this being an indication that rejection of the method is based solely on the fact that human embryonic stem cells are used.

\section{Importance of the Technique Used in the Non-Embryo-Destructive Procedure for the Embryo $\nabla$}

The properties and the importance of human embryonic stem cells for potential medical therapies has been discussed previously and reported on in great detail; readers should refer to the relevant literature for more information on this point $[9,10]$. Moreover, the medical benefits are irrelevant for the observations discussed below. With regard to the technique used for the procedure described by Dittrich et al. [1], it should be noted that the authors refer to an earlier publication of theirs [11] and to patent DE 102004062 184, which is held by some of the authors. This patent shows that the evidence showing that the described procedure, which was subsequently patented for use in human blastocysts, is technically feasible was obtained from experiments in a mouse model. According to the publication [11], healthy offspring were born to mice after the storage of stem cells obtained from blastocysts. But in their current article the authors kept quiet about those aspects of their earlier research which, from a legal point of view, would militate against the method being approved for use in human cells. Their current publication creates the impression that success, as measured by healthy offspring, is guaranteed. A look at the earlier publication raises legally relevant doubts about the transfer of the method for use in human embryos. In the original publication 40 mouse blastocysts were biopsied. Only 24 blastocysts survived the procedure; these surviving blastocysts were then transferred into four foster mice. One foster mouse subsequently gave birth to two offspring. There is no intention here to belittle the technical achievement of this procedure, given that - as the authors correctly stated - it is much more difficult to obtain embryonic stem cells from blastocysts while preserving the embryo than it is to obtain stem cells by destroying the blastocysts. The authors have found a solution to this problem which is feasible in an animal model but, given the inherent risks for the blastocyst associated with this method, it cannot be used for human blastocysts because of the basic prohibition defined in Art. 2 Sect. 1 ESchG.

It is also important to note that in their current publication, which was published around ten years after the patent application of 2004 referred to in their current publication and in the publication which they refer to both in the current publication and in the patent application, Dittrich et al. [1] do not mention any more recent literature or results which show higher rates of success in preserving the embryo and extracting embryonic stem cells than those reported in paper from ten years ago and more. Why? Moreover, a careful study of the matter found that the nonembryo-destructive harvesting of embryonic stem cells does not appear to play a role in any other legal systems either, at least with regard to human embryos. A search of PubMed, even with the help of the keywords used by Dittrich et al. [1], found no other notable publications on any relevant research efforts.

\section{PIGD of Totipotent Stem Cells Extracted by Non-Embryo-Destructive Methods $\nabla$}

Performing PIGD during a biopsy and examining the totipotent cells (at the morula stage) is strictly forbidden; there are no exceptions to this prohibition and it holds irrespective of whether the procedure preserves or destroys the "embryo remnant" because even individual totipotent cells extracted from the multicellular embryo during the blastomere development stage are le- 
gally classified as embryos in their own right under Art. 8 Sect. 1 ESchG. The deliberate destruction of such a biopsied cell, which is necessary in PIGD, is therefore forbidden under Art. 2 Sect. 1 ESchG. Moreover, because of the legal classification of the biopsied cell as an "independent" embryo in Art. 6 Sect. 1 ESchG, the splitting off of even a single totipotent cell from a multicellular embryo is classified as cloning (which is forbidden), because this splitting off results in the artificial creation of another embryo which is genetically identical to the original embryo $[12,13]$. Any embryo-preserving biopsy which utilizes totipotent stem cells with the aim of creating a culture of stem cells is therefore also forbidden and for the same reasons.

\section{PIGD of Pluripotent Stem Cells Obtained by Non-Embryo-Destructive Harvesting \\ $\nabla$}

As the aim of PIGD is to obtain (genetic) information about the (remaining) embryo, it is self-evident that PIGD procedure must preserve the embryo. But damage to the remaining embryo can still always occur as a consequence of the residual risk associated with every type of technology or simply as a result of human error. Biopsies of embryonic cells which are no longer totipotent for the purpose of examining the obtained cells with PIGD are still generally prohibited in Germany, even after the last reform [14] of the German Embryo Protection Act (cf. Art. 3a Sect. 1 ESchG). PIGD is only permitted in exceptional cases such as those defined in Art. 3 a Sect. 2 ESchG and only under the circumstances described there. The conditions permitting this exemption are considered to have been met if, because of the genetic makeup of the mother who provides the egg cell or of the father who provides the sperm cell or both, their offspring are at risk of a serious inheritable genetic disease or if findings point to a serious malformation of the embryo, with a high probability that this will lead either to stillbirth or miscarriage. Additional legal pre-conditions for PIGD are that the mother is given information and counseling prior to carrying out PIGD if the PIGD procedure has been approved, after due consideration, by an interdisciplinary ethics committee. Above all, the aim of any PIGD must be to produce a pregnancy in the woman who provided the egg cell as long as the embryo does not show any genetic variations which indicate that it should not be transferred.

As the law does not specify which embryonic cells can be used for PIGD, in principle both trophectoderm biopsy and biopsy of cells from the inner cell mass are legally permitted. The destructive examination of the biopsied, non-totipotent cells is legal because these cells are not classified as embryos, do not enjoy individual legal protection, and are legally treated the same as cells from any other cell or tissue donation (cf. also [15]). However, the respective risk to the continued existence and development of the examined embryo associated with both aforementioned types of biopsy has a significant impact on which procedure is ultimately permissible.

The likelihood that PIGD will be safe as regards the preservation of the embryo has been discussed less often in the literature than actual implementation of the procedure. In contrast to the typical information available in doctor's practices, Dittrich et al. [1] do not mention that a biopsy can cause the embryo to lose its capacity to develop further. Instead, Dittrich et al. [1] focus on the potentially more precise results provided by an examination of cells from the inner cell mass biopsied using the non-embryo-destructive method they have described, compared to trophecto- derm biopsies which are also embryo-preserving procedures but represent a different type of risk for the embryo. The information and counseling about the different types of risk is extremely important for the examining physician, the affected couple and the ethics committee which must decide, pursuant to Art. 3 a ESchG and the Pre-implantation Genetic Diagnosis Regulation (PIDV), on the application for PIGD, because this is the only information - together with the quality of the test results - which will put affected potential parents in a position to decide whether PIGD should be carried out in their specific case.

\section{Extraction and Storage of Pluripotent Stem Cells Using Non-Embryo-Destructive Methods \\ $\nabla$}

The non-embryo-destructive extraction of pluripotent stem cells from the inner cell mass for the purpose of storing these stem cells is prohibited in Germany, and violations could result in criminal prosecution, even for the type of procedure described by Dittrich et al. [1]. These procedures are not permitted as they are not conducive to preserving the embryo. This also applies to so-called non-embryo-destructive procedures as ultimately such procedures are always associated with a residual risk of destroying the embryo and, in addition, the biopsy does not benefit the embryo in terms of its further development. In Art. 2 Sect. 1 ESchG, the Embryo Protection Act defines all actions affecting the embryo in vitro which are not designed to preserve the embryo as illegal acts and punishes such conflicting behavior with imprisonment for up to three years or a fine.

It should also be noted that, given the typical reasons to carry out medically assisted reproduction, it is not clear what "market" would exist for non-embryo-destructive stem cell harvesting using the procedure described by Dittrich et al. [1]. If PIGD is carried out and the findings show that the embryo has a serious malformation that, in all probability, will result in stillbirth or miscarriage, then the affected embryo will be discarded. The storage of stem cells with preservation and transfer of the embryo is not anticipated in these cases as in the foreseeable future, even using the stored cells, no therapy is possible for the type of diseases detected with PIGD. The "preimplantation therapy" mentioned by Dittrich et al. [1] is, as the authors wrote themselves, "still looking ahead to the future" although it should additionally be pointed out here that this is looking ahead to an uncertain future which, even taking the speed of medical progress into account, is probably looking ahead to a far distant future which will not benefit any embryo whose stem cells are stored today or within the foreseeable future. Because of the complexity of genetic diseases, the current goal of PIGD is to ensure that only those embryos are transferred which do not appear to have genetic defects which would result in a serious malformation leading in all probability to stillbirth or miscarriage. Following PIGD, it is still currently forbidden to obtain stem cells from an embryo which was not transferred due to genetic malformations found during preimplantation genetic diagnosis, particularly if stem cell extraction would destroy this embryo; this applies even if these cells could be used to create cell lines which could be used to investigate the genetic causes of the disease which led to the affected embryo not being transferred. The reason for this prohibition is that even embryos such as those described above, as long as they are still considered to be capable of further development within the meaning of the Embryo Protection Act, are embryos as defined in Art. 8 Sect. 1 ESchG, and they may therefore not be destroyed for any third- 
party purpose such as obtaining stem cells. The only possible option here is to "keep" the affected embryos for a long time until they are no longer capable of further development, as in this case they would no longer be embryos as defined by the Embryo Protection Act $[16,17]$. But this would also defeat the purpose of extracting any qualitatively viable stem cells.

If we speculate that PIGD is not being carried out but "only" medically assisted reproduction, it is difficult to imagine that, after being properly informed about the procedure, the affected couples would consent to any so-called non-embryo-destructive extraction of stem cell from the inner cell mass. The reason for this is that, as described above, the attending physician must always inform the potential parents about the associated risk to the embryo. The physician would currently be obliged to inform the potential parents with reference to the publication by Dittrich et al. [1] that animal models have shown that in $40 \%$ of cases, it is probable that the embryo will not survive the procedure. Even if the success rate of the procedure improves, thereby reducing the risk to the embryo, technical procedures are always associated with a residual risk, either related to the technique itself or to human error. When explaining the risks to patients, the physician cannot and may not promise a $100 \%$ success rate with regard to preservation of the embryo following the extraction of stem cells. Instead, the information given by the physician must consist of realistic figures. If you then consider the (limited) number of embryos available to a couple for in-vitro fertilization, the success rates of medically assisted reproductive technologies of approximately $15 \%$ per IVF cycle, even without the addition of any invasive procedures affecting the created embryo [18], and the circumstances of the couples who have turned to medically assisted reproduction, it is very unlikely that these couples would consent to such a procedure, which would additionally offer no benefits for the affected embryo but would instead be associated with (additional) risks militating against a successful pregnancy. Without wishing to comment on the quality of different stem cell types for various therapeutic purposes, it is also worth considering that storage of umbilical cord blood stem cells or generation of iPS cells is far less invasive and involves much less risk for the embryo compared to so-called non-embryo-destructive stem cell harvesting from the blastocyst. Moreover, the utilization of the biopsied cells is uncertain, meaning that the potential benefit to the person who would be born, a benefit based only on the biopsied and stored cells, would be out of all proportion to the risk involved for the embryo. The physician would also be obliged to inform the parents about these circumstances prior to carrying out the PIGD as these aspects are essential for the affected couple's decision.

Ultimately it does not matter whether there might be a small legal loophole which would permit the non-embryo-destructive harvesting of stem cells from the inner cell mass for therapeutic purposes for the benefit of the biopsied embryo. Such "therapies" appear to be largely theoretical or legalist, as it would be necessary to ensure that the biopsied cells are only used to treat the embryo from whom they were biopsied. Are any such therapies available? We would rather have to assume that an embryo, in whom a sufficiently serious genetic defect was diagnosed during PIGD, the effects of which could theoretically be treated by utilizing the embryo's stem cells, would simply not be transferred, so that the therapeutic option as such does not exist.

\section{Patenting the Non-Embryo-Destructive Harvesting of Pluripotent Stem Cells \\ $\nabla$}

Patent DE 102004062184 on the non-embryo-destructive harvesting of stem cells mentioned by Dittrich et al. [1] and held by some of the authors contravenes the higher-ranking jurisdiction of the ECJ. The patent must be measured against the reasons for granting and the reasons for rejecting a patent application defined in Articles 1 a \& 2 of the German Patent Act (PatG) which regulate the patenting of inventions developed on the basis of substances of human origin and which also serve to implement the higher-ranking directive law of the European Union. Specifically in this case, this concerns the implementation of the Biopatent Directive 98/44/EC. Because the relevant German norms are subject to and dependent on the higher-ranking system of norms defined in the Bio-patent Directive, the interpretation and application of the German norms is guided by the interpretation of the relevant higher-ranking laws of the European Union. When applying the German norms of the German Patent Act which take their origins from EU law, German (patent) authorities must also take the jurisdiction of the ECJ into account (on this obligation of German authorities in general, cf. $[19,20]$ ).

German bio-patent law is shaped and guided by the EU's Bio-patent Directive. In the so-called Brüstle judgement and in its ruling on parthenotes, the ECJ ruled that technologies which make use of human embryonic stem cells are not patent eligible if they are based on the destruction or even the utilization of human embryos which have the capacity to develop further, because the ECJ has granted embryos their own rights under the constitutional law of the European Union which aims to protect embryos against destruction or other forms of utilization [7,21]. As regards the revocation of the patent, it does not matter whether the obtaining of embryos is even mentioned in the patent document, as the destruction or utilization of embryos as such is viewed as judicially deprecated and this affects all dependent follow-on products and procedures. This was intended to prevent the possibility that the judicially deprecated destruction or utilization of human embryos could be circumvented by the clever wording of patent documents [22]. Any patenting of such inventions would be tantamount to the exploitation and commercialization of a human not intended by the legislators. In patent law, the ECJ has ruled that this type of destruction or utilization of human embryos conducted for the purposes of a third party (a third party, because the embryos from whom the cells are harvested would not benefit, only others would) is incompatible with the European Union ordre public provisions in Art. 6 of the Bio-patent Directive which states that such inventions cannot be patented. The ECJ differentiates between the "destruction" and the "utilization" of embryos, so there is obviously a difference between embryo destruction and embryo utilization. The utilization of an embryo "only" for the purpose of harvesting stem cells does not necessarily involve the destruction of the embryo. However, the ECJ has placed destruction and utilization on the same legal footing and considers that both constitute an infringement of the ordre public provisions under the laws of the European Union [7]. Therefore, in patent law, the non-embryo-destructive extraction of stem cells is nothing else but a procedure affecting human embryos incompatible with the ordre public concepts of European law; the consequence is that interventions which are based on stem cells harvested in this way, irrespective of the manner of extraction referred to in the patent document, are not patent eligible under the Bio-patent Directive and therefore also under Ger- 
man patent law. The German Patent and Trademark Office (DPMA) has mistaken the context and therefore, in terms of substantive law, illegally granted the patent referred to by Dittrich et al. [1].

It is also not possible to deduce that this type of technique for harvesting stem cells which affects the embryo would be patent eligible from any judicial decisions of the German Federal Court of Justice (Bundesgerichtshof, BGH) based on the Brüstle ruling which was issued based on a submission by the BGH to the ECJ [23]. The oft cited argument that the BGH regards such techniques as basically patent eligible is incorrect, as the $\mathrm{BGH}$ did not comment in the relevant ruling on non-embryo-destructive procedures which refer to embryos as defined in patent law (and in the Embryo Protection Act). In the ruling by the BGH it is not comprehensible why the $\mathrm{BGH}$, following remarks on the harvesting of "embryonic" stem cells from primordial germ cells asserted that the fact that the patent document has not shown other ways of obtaining embryonic stem cells without destroying human embryos is not at variance with the admissibility of the patent claims. The disclosure of one of several feasible paths by which one stage of the procedure could be "generically" carried out would suffice, if the stage, in general and after due consideration, is also part of the solution [23]. It needs to be stated that, firstly, the harvesting of "embryonic" stem cells from the primordial germ cells of dead fetuses or dead embryos at the age of several weeks is substantially different (technically) from the nonembryo-destructive extraction of embryonic stem cells from human embryos in the blastocyst development stage when the blastocysts still have the capacity to develop further. Secondly, the fetuses or embryos are dead, and therefore no longer embryos as defined in patent law. Moreover, when the fetuses or embryos are dead, non-fetus or non-embryo-destructive harvesting no longer plays a role with regard to the continued, but no longer existing capacity of the embryo to develop further. This alone shows that the production of "embryonic" stem cells from primordial germ cells cannot be considered as a disclosure of one of several feasible paths by which one stage of the procedure could be "generically" carried out. The same also applies to another, allegedly embryo-preserving procedure which the BGH discusses: the harvesting of embryonic stem cells from arrested embryos. Just as miscarried fetuses or embryos are not embryos within the meaning of patent law as they have no capacity to develop further, arrested embryos are also not embryos within the meaning of patent law as they also do not have the capacity to develop further. The BGH even expatiates on this point [23]. Such arrested embryos are typically "destroyed" during stem cell harvesting, so that the procedure cannot be classified as not non-destructive of the (dead) embryo. In other words: in its ruling the BGH has taken into consideration the fact that procedures do exist in which stem cells can be obtained from entities which are not embryos in the legal sense of the term because these entities have lost their capacity to develop further. But the BGH does not appear to have considered the case of embryo-preserving procedures in which the embryo (in the legal sense defined in patent law) is not destroyed but only utilized.

In contrast to the remarkable adjudication of the ECJ on this point, the restrictive features which the BGH ruled to be admissible for the patent claim (disclaimer) which stated that "it will not include any isolated purified precursor cells from human embryonic stem cells obtained through the destruction of embryos" do not explicitly exclude non-embryo-destructive procedures which utilize embryos to harvest stem cells from patent protection, thereby violating Art. 6 Sect. 2c) Rule 98/44/EC. The DPMA also did not recognize this point when granting the patent referred to by Dittrich et al. [1]. It remains to be seen whether this patent can be upheld against a possible invalidity action filed against it, which would enlarge upon the higher-ranking interpretation of Rule $98 / 44 / \mathrm{EC}$ by the ECJ. It is also important to bear in mind that the so-called Brüstle patent was initially granted for human stem cells, but was subsequently declared invalid by the BGH for those embodiments which require the destruction of human embryos in the course of legal procedures held over several years.

Finally, it is astonishing that the procedure to grant the patent referred to by Dittrich et al. [1] initially discusses the fact that the German patent in question cannot be implemented in Germany because of the prohibitions of the Embryo Protection Act (see above) [24]. But during the further course of proceedings the DPMA erroneously let itself be deterred from following up this line of argumentation [25]. This statement that the procedure is not feasible because of the legal impediments is crucial because Art. 2 Sect. 1 PatG states that patents will not be granted to inventions whose commercial utilization would constitute a violation of public order or a violation of common decency, even if such a violation cannot be deduced merely from the fact that utilization of the specific invention is prohibited by law or administrative regulations.

Dittrich et al. [1] also kept quiet about the fact that the European patent application EP1674563A1 which was based on their German patent was rejected by the EPO's Board of Appeal. To understand this, it is important to know that for historical reasons Europe has two independent patent protection regimes, each of which offer an equivalent protection, and it is up to the inventor to decide which one he would like to use; on the one hand there are the national patent systems of the individual nations in the European Union, some of which have been harmonized by European Union law such as the Bio-patent Directive, and on the other hand there is the European Patent Convention which was created through international treaties between European nations. When the application for an EPC patent was filed, a patent for non-embryo-destructive stem cell extraction was also applied for which also covered human blastocysts. The EPO examining division rejected it on the grounds that the subject matter of the patent claim was excluded and not patent eligible under Art. 53a) in conjunction with Rule 28c) EPC, as even the non-destructive utilization of human embryos in which embryos were the base material for a procedure to extract embryonic stem cells for commercial utilization must be considered a "utilization for industrial or commercial purposes" as defined in Rule 28c) EPC. The appeal lodged against this decision with the EPO's Board of Appeal was disallowed for formal legal reasons; however the Board of Appeal commented, at least indirectly, on the issue of the patent eligibility of such interventions.

In a subsequent appeal procedure, the applicants attempted to overcome the objections of the examining division by including a disclaimer in their claim. According to this disclaimer, harvested embryonic stem cells would not be used in industrial or commercial applications if the blastocyst was a human blastocyst. But the Board of Appeal did not allow the disclaimer as it considered that the disclaimer constituted an attempt to put a future utilization to one side and could not be considered a procedural step of the process for which the claim was being filed and that the disclaimer did not limit the actual patent claim in any way. The disclaimer was therefore judged to be contrary to Art. 123 Sect. 2 EPC and Art. 84 EPC, which state that a disclaimer 
which may potentially be necessary should not exclude more than what is required to preclude the matter excluded from patent protection for non-technical reasons and that patent claims must be formulated clearly and concisely and must be supported by a description of the object to be patented [26].

In its further observations, the Board of Appeal agreed with the statements of the examining division and stated in an obiter dictum that with regard to the patent claim and the disclaimer the Board of Appeal was of the same opinion, as was the examining division with regard to the patent claim and the disclaimer, with respect to human blastocysts the patent claim was covering matters which violated Art. 53a) in conjunction with Rule 28c) EPC, because using human embryos as the base material in a procedure carried out purely to obtain embryonic stem cells for commercial applications must be considered a "utilization for industrial or commercial purposes" as defined in Rule 28c) EPC and was therefore not compatible with the EPC. The Board of Appeal referred in this context to the ruling of the $\mathrm{ECJ}$ in the "Brüstle" case [27]. Even if the ECJ, as the highest authority in this matter, has given a clear answer to the question of the non-embryo destructive extraction of stem cells, for the EPC the final ruling on this issue will have to be decided in proceedings initiated with the Enlarged Board of Appeal.

\section{Conclusion \\ $\checkmark$}

In Germany, the non-embryo-destructive harvesting of stem cells is prohibited under criminal law. Therefore, if practitioners of reproductive medicine offer this procedure, they are at significant risk of criminal liability, even if they inform their patients carefully about the procedure and the patients consent to the procedure. The penal prohibition does not take that into account. But such violations by physicians can also have professional consequences as it could raise doubts about their credibility as a physician. The relevant German patent for the non-embryodestructive extraction of stem cells runs a high risk of being repealed in invalidity proceedings. If society wants non-embryodestructive stem cell harvesting then, to be legally coherent, that will only be possible by changing non-constitutional laws. Whether such an approach would be possible and would comply with current constitutional law is still controversial, but it has been posited several times in academic discussions (e.g. $[5,6]$ ). But this paper does not aim to answer this question, which should be left to further academic debate and would ultimately be the remit of politicians and of the legislature.

\section{Conflict of Interest \\ $\nabla$}

None.

\section{References}

1 Dittrich R, Beckmann MW, Würfel W. Non-embryo-destructive extraction of pluripotent embryonic stem cells: implications for regenerative medicine and reproductive medicine. Geburtsh Frauenheilk 2015; 75: 1239-1242

2 Thomson JA, Itskovitz-Eldor J, Shapiro SS et al. Embryonic stem cell lines derived from human blastocysts. Science 1998; 282: 1145-1147

3 Schmidt-Bleibtreu B, Hofmann H, Henneke HG, Hrsg. Grundgesetz Kommentar. 13. Aufl. Köln: Carl Heymanns; 2014: Hofmann, Art. 2, Rdnr. $62 \mathrm{ff}$

4 Sachs M. Grundgesetz - Kommentar. 7.Aufl. München: C. H. Beck; 2014: Höfling, Art. 1, Rdnr. 255

5 Dreier H, Hrsg. Grundgesetz - Kommentar, Bd. 1. 3. Aufl. Tübingen: Mohr Siebeck; 2013: Dreier, Art. 1 I, Rdnr. 79 ff., 86 ff

6 Enders C. Art. 1, Rdnr. 1337. In: Friauf KH, Höfling W, Hrsg. Berliner Kommentar zum Grundgesetz, Stand: 49. Ergänzungslieferung. Berlin: Erich Schmidt Verlag; Februar 2016

7 EuGH Rechtssache C-34/10, Urteil vom 18.11.2011, Rdnr. 52

8 Entscheidung der Großen Beschwerdekammer, G 2/06 (T 1374/04, Stammzellen/WARF) vom 07.04.2006, Entscheidungsgründe, Rdnr. 15, 25 = GRUR Int 2010; 59: 230-236

9 Ilic D, Devito L, Miere C et al. Human embryonic and induced pluripotent stem cells in clinical trials. Br Med Bull 2015; 116: 19-27

10 Whiting P, Kerby J, Coffey P et al. Progressing a human embryonic stemcell-based regenerative medicine therapy towards the clinic. Philos Trans R Soc Lond B Biol Sci 2015; 370: 20140375

11 Dittrich $R$, Lotz L, Würfel W et al. Offspring after embryo-preserving biopsy of the embryoblast with standard ICSI equipment in mouse blastocysts. In Vivo 2011; 25: 935-939

12 Günther HL. §6, Rdnr. 3, 9. In: Günther HL, Taupitz J, Kaiser P, Hrsg. Embryonenschutzgesetz - Juristischer Kommentar mit medizinisch-naturwissenschaftlichen Einführungen. 2. Aufl. Stuttgart: Kohlhammer; 2014

13 Müller-Terpitz R. § 6 ESchG, Rdnr. 2. In: Spickhoff A, Hrsg. Medizinrecht 2. Aufl. München: C. H. Beck; 2014

14 Gesetz zur Regelung der Präimplantationsdiagnostik - Präimplantationsdiagnostik-PräimG. Bundesgesetzblatt 2011, Teil I, Nr.58 vom 24.11.2011, 2228-2229

15 Wendehorst C. Art. 43 EGBGB, Rdnr. 30. In: Säcker FJ, Rixecker R, Oetker H, Hrsg. Münchener Kommentar zum Bürgerlichen Gesetzbuch, Bd. 12 . 6. Aufl. München: C. H. Beck; 2015

16 Faltus T. Die Bedeutung des Urteils des Bundesgerichtshofes zur Präimplantationsdiagnostik für die Regenerative Medizin. Regenerative Medizin 2011; 4: 32-36

17 Taupitz J. § 8, Rndr. 20 ff. In: Günther HL, Taupitz J, Kaiser P, Hrsg. Embryonenschutzgesetz - Juristischer Kommentar mit medizinisch-naturwissenschaftlichen Einführungen. 2. Aufl. Stuttgart: Kohlhammer; 2014

18 Wischmann T. Einführung Reproduktionsmedizin. 1. Aufl. München: Ernst Reinhardt Verlag; 2012: 80-92

19 Herdegen M. Europarecht. 17. Aufl. München: C. H. Beck; 2015: §9, Rdnr. 35, § 10, Rdnr. 1

20 Bieber R. $§ 4$, Rdnr. 5 ff. In: Bieber R, Epiney A, Haag M, Hrsg. Die Europäische Union - Europarecht und Politik. 11. Aufl. Baden-Baden: Nomos; 2015

21 EuGH Rechtssache C-364/13, Urteil vom 18.12.2014, Rdnr. 30, Tenor

22 EuGH Rechtssache C-34/10, Urteil vom 18.11.2011, Rdnr. 50

23 BGHZ Urteil vom 27. November 2012, Az. X ZR 58/07 = BGH GRUR 2013; 115: 272-275

24 Blatt 28 der Patentakte zur Patentanmeldung DE 102004062184.5 zum später erteilten Patent DE 102004062184

25 Blatt 35, 43 der Patentakte zur Patentanmeldung DE 102004062184.5 zum später erteilten Patent DE 102004062184

26 Beschwerdekammer des Europäischen Patentamts, Beschwerde-Aktenzeichen T 1836/10-3. 3.08, Entscheidung vom 09.04.2013, Entscheidungsgründe, Rdnr. $9 \mathrm{ff}$

27 Beschwerdekammer des Europäischen Patentamts, Beschwerde-Aktenzeichen T 1836/10-3. 3.08, Entscheidung vom 09.04.2013, Entscheidungsgründe, Rdnr. 10 